\title{
Kognitivno-bihevioralna terapija djeteta sa selektivnim mutizmom
}

\section{Cognitive behavioral based treatment of selective mutism}

\author{
Ana Kordić*, Daria Sfeci, Lea Slavčić, Ljubica Paradžik
}

Psihijatrijska bolnica za djecu i mladež, Zagreb, Hrvatska

\author{
*Dopisni autor: \\ Ana Kordić, mag. psych., klinički psiholog \\ Psihijatrijska bolnica za djecu i mladež, \\ Zagreb, Hrvatska \\ I. Kukuljevića 11, 10000 Zagreb \\ e-mail: ana.jailhouse@gmail.com
}

\begin{abstract}
Sažetak. Cilj: U ovoj studiji slučaja bit će predstavljen kognitivno-bihevioralni tretman djeteta s dijagnozom selektivnog mutizma, uz naglasak na važnosti multidisciplinarnog pristupa te važnosti uloge roditelja kao koterapeuta u procesu tretmana. Prikaz slučaja: Dječak u dobi od 6 godina i 8 mjeseci dolazi na prvu psihijatrijsku procjenu u Psihijatrijsku bolnicu za djecu i mladež u Zagrebu u pratnji roditelja, a po preporuci pedijatra. Prema navodima roditelja dječak je prije 5 mjeseci prestao komunicirati s vršnjacima, kao i s odraslima izvan obitelji. Dječak ne ide na dječje rođendane niti kod prijatelja na igru te zahtijeva stalnu prisutnost roditelja. Roditelji smatraju kako je okidač za prekid verbalne komunikacije bila hospitalizacija dječaka zbog drugih zdravstvenih problema, zbog čega je neko vrijeme bio odvojen od roditelja. Nakon multidisciplinarne obrade dječak je uključen u kontinuirani tretman psihologa i logopeda. Psihološki tretman odvijao se kroz godinu i pol dana, u ukupnom trajanju od 28 susreta, a dječak je za to vrijeme napredovao od toga da može razgovarati isključivo s bliskim članovima obitelji, do toga da može komunicirati s raznim ljudima izvan obiteljskog okruženja te bez teškoća funkcionirati u školi. Zaključak: Ovaj prikaz slučaja ukazuje na efikasnost kognitivno-bihevioralne terapije u tretmanu anksioznih poremećaja, što je u skladu $s$ relevantnim znanstvenim istraživanjima. Pritom je stavljen naglasak na važnost multidisciplinarnog pristupa u interakciji između terapeuta, roditelja, škole te ostalih važnih sudionika u djetetovu okruženju.
\end{abstract}

Ključne riječi: anksioznost; kognitivno-bihevioralna terapija; multidisciplinarni pristup; selektivni mutizam

Abstract. Aim: In this case study, a cognitive behavioral treatment of child with a selective mutism diagnosis will be presented, highlighting the importance of multidisciplinary approach and importance of parents being co-therapists during the treatment. Case report: A boy, 6 years and 8 months old, was brought by his parents to his first psychiatric examination to the Psychiatric hospital for Children and Adolescents in Zagreb, to which he was referred by his physician. According to his parents, 5 months ago he stopped communicating verbally with his peers and adults outside of family setting. The boy doesn't attend children's birthdays, nor does he go to his friend's houses to play, demanding parent's presence all day long. Parents believe that the problem was triggered by the boy's hospitalization and separation from parents, due to his medical issues. After the multidisciplinary examination the boy was included in continuous treatment of both psychologist and speech therapist. Psychological treatment lasted for 1,5 year and included 28 sessions in total. During the treatment, the boy improved from being able to speak only with close family members to being able to communicate openly with other people in public setting, e.g. at school. Conclusion: This study indicates efficiency of cognitive behavioral therapy in treating anxiety disorders, which is accordant to relevant scientific research. This case study places importance on the multidisciplinary approach in interaction between therapist, parents, school and all other relevant participants in the child's social environment.

Key words: childhood anxiety; cognitive behavioral therapy; multidisciplinary treatment; selective mutism 


\section{UVOD}

Selektivni mutizam kod djece odnosi se na doživljaj anksioznosti tijekom komunikacije u socijalnim situacijama ili sa specifičnim osobama ${ }^{1}$. Djeca sa selektivnim mutizmom stekla su sposobnost verbalne komunikacije, no usprkos tome nisu u mogućnosti verbalno komunicirati u određenim situacijama. Tako, primjerice, u obiteljskom okruženju mogu uobičajeno komunicirati, dok u vrtiću ili u školi komunikacija može potpuno izostajati. lako se ranije selektivni mutizam smatrao ekstremnim oblikom socijalne fobije, novija istraživanja to ne potvrđuju ${ }^{2,3}$. Postoji nekoliko argumenata koji govore u prilog tome da selektivni mutizam nije oblik socijalne fobije. Prvo, djeca sa selektivnim mutizmom izvještavaju o nižoj razini anksioznosti od osoba sa socijalnom fobijom. Naime, u istraživanju Melfsen i sur. ${ }^{3}$ djeca sa selektivnim mutizmom imala su niže rezultate od djece sa socijalnom fobijom na upitniku SPAIK (upitnik socijalne fobije i anksioznosti), što pokazuje da selektivni mutizam nije ekstremni oblik socijalne fobije. To se potvrdilo i u istraživanju Yaganeh i sur. ${ }^{2}$ u kojem je dobiveno da djeca sa selektivnim mutizmom imaju umjerenu razinu socijalne anksioznosti. Drugi argument je razlika u dobi javljanja poremećaja i kognitivni razvoj djeteta. Selektivni mutizam javlja se između treće i pete godine života, dok se socijalna fobija najčešće javlja između jedanaeste i trinaeste godine. U dobi javljanja selektivnog mutizma djeca nisu dovoljno kognitivno razvijena da bi razvila socijalnu fobiju. Treći argument odnosi se na razliku u prognozi ovih dvaju poremećaja. Kod selektivnog mutizma može doći do spontanog izlječenja, dok kod socijalne fobije to nije slučaj ${ }^{3}$.

Autori sistemsko-obiteljskog pristupa smatraju da je selektivni mutizam izraz disfunkcionalnosti obiteljskog sustava ${ }^{4}$. Kao dva etiološka čimbenika koja su vezana uz obiteljsko funkcioniranje navode strah od izdaje obiteljskih tajni i otpor prema majci koja se prema djetetu ponaša prekomjerno ovisnički. Autori ovog usmjerenja navode kako disfunkcionalne obitelji djece sa selektivnim mutizmom karakterizira ekstremna emocionalna povezanost djeteta i majke, pasivnost oca te sramežljivost ostalih članova obitelji. Takvi odnosi remete individualni razvoj djeteta te otežavaju razvoj društvenih odnosa s ljudima izvan obitelji. Autori nadalje tvrde kako u takvim obiteljima roditelji kontroliraju neprijateljske stavove prema ljudima izvan obitelji i projiciraju ih na dijete koje postaje nepovjerljivo prema okolini te prima poruku da je prisutnost roditelja neophodna za preživljavanje. Prema ovom shvaćanju selektivni mutizam može se gledati kao obrambeni mehanizam za osjećaje ranjivosti i opasnosti koji se javljaju kada roditelji nisu u blizini, te se tretirati kao forma separacijske anksioznosti ${ }^{4}$.

Selektivni mutizam rijedak je poremećaj koji se javlja u djetinjstvu, kada govor djeteta selektivno izostaje u određenim anksiogenim socijalnim situacijama. Etiološki faktori nisu precizno definirani, a različita teorijska shvaćanja daju svoja tumačenja. Suvremeni tretman selektivnog mutizma upućuje na efikasnost kognitivno-bihevioralne terapije u liječenju poremećaja, kao i važnost eklektičkog pristupa.

Selektivni mutizam obično se javlja u dobi između 3. i 5. godine, a prevalencija se prema procjenama kreće između 0,18\% i 1,9\% ${ }^{5}$. Selektivni mutizam najčešće je u komorbiditetu sa socijalnom anksioznošću, socijalnom fobijom i specifičnom fobijom te nešto rjeđe sa separacijskom anksioznošću ${ }^{6}$.

Okolinski faktori koji mogu utjecati na razvoj ovog poremećaja su obiteljska dinamika, disfunkcionalni obrasci nagrađivanja, prijašnji poremećaji prilagodbe, doživljaj stresa zbog jezične ili kulturalne akulturacije $^{7}$. Kod roditelja djece sa selektivnim mutizmom utvrđena je viša razina anksioznosti te visoka razina anksioznih reakcija na socijalne situacije $^{8}$.

Kao terapije izbora u liječenju selektivnog mutizma indicirane su kognitivno-bihevioralna, grupna obiteljska te psihosocijalna terapija, uz primjenu psihofarmaka ${ }^{9}$. Kombinacijom ovih postupaka moguće je promijeniti djetetove načine percepcije i suočavanja s teškoćama u društvenom okruženju. Eventualno uvođenje psihofarmaka treba odobriti dječji i adolescentni psihijatar, i to kod težih oblika anksioznih poremećaja koji značajno narušavaju sveopće funkcioniranje djeteta ${ }^{10}$. 
Neke od negativnih posljedica neprepoznavanja i netretiranja selektivnog mutizma kod djece jesu slabije razvijene socijalne vještine te moguće odbacivanje od strane vršnjaka ${ }^{11}$.

\section{PRIKAZ SLUČAJA}

Dječak u dobi od 6 godina i 8 mjeseci dolazi na prvi pregled psihijatra u Psihijatrijsku bolnicu za djecu i mladež u Zagrebu, prema uputi pedijatra. Kao razlog dolaska roditelji navode da kod dječaka unazad 5 mjeseci izostaje verbalna komunikacija s djecom i odraslim osobama izvan uže obitelji (verbalno komunicira isključivo s roditeljima i starijom braćom kada su sami kod kuće, a u prisustvu drugih ljudi s roditeljima komunicira šapatom). Do tada je verbalno komunicirao s djecom u vrtiću i odgajateljima, ali oduvijek oskudnije i često šapatom. Kad mu se obraćaju nepoznati ljudi, skriva se iza roditelja te komunicira isključivo kimanjem glave. Dječak ne ide na dječje rođendane niti kod prijatelja na igru te odbija ostati sam na pregledima kod liječnika i ostalih stručnjaka, zahtijeva stalnu blizinu roditelja. Ako majka ili otac u pratnji pokušaju napustiti ordinaciju liječnika ili drugog stručnjaka, dječak izlazi za roditeljem te pri anticipaciji separacije od roditelja postaje uznemiren. Kao okidač za prekid verbalnog komuniciranja roditelji navode hospitalizaciju izvan mjesta boravka zbog respiratornih poteškoća, gdje je nekoliko dana bio odvojen od roditelja. Zbog liječenja, na kojemu je bio nekoliko puta kroz godinu dana, često je izostajao iz vrtića te mijenjao vrtićke grupe (prilagođavanje na novu djecu i nove odgajatelje).

Dječak je rođen u cjelovitoj obitelji iz majčine treće uredne trudnoće, rani psihomotorni razvoj odvijao se s kašnjenjem s obzirom na očekivano za dob - prohodao je s kašnjenjem (18 - 20 mjeseci), progovorio je smislenije riječi tek s 24 mjeseca. Sfinkter kontrolira s oko 4 i pol godine. Roditelji ga opisuju kao oduvijek povučenog i stidljivog dječaka slabijeg apetita, u socijalnim interakcijama je oduvijek pokazivao slabiju inicijativu i spontanost te preferirao male skupine djece. Dječak od rođenja spava s roditeljima u sobi te roditelji navode kako iz financijskih razloga nisu u mogućnosti napraviti dječaku odvojenu sobu. Roditelji negiraju psihijatrijski hereditet u užoj i široj obitelji. Traumatske i upalne bolesti glave i Sžs-a također negiraju, kao i konvulzije.

Nakon pregleda psihijatra dječak je upućen na multidisciplinarnu timsku obradu (psihijatar, psiholog, logoped, neurolog, EEG). Dječak je na pregledima pokazivao slabiju suradnju te visoku anksioznost pri pokušaju separacije od roditelja. Pregledom psihologa utvrđen je disharmoničan kognitivni profil s prosječnim vrijednostima u zadacima neverbalnog tipa te graničnim vrijednostima u zadacima verbalnog tipa, uz naglašenu socijalnu anksioznost. Neurološkim pregledom te EEG-om ne nalaze se odstupanja. Psihijatar nije pripisao psihofarmak. Zaključkom timske obrade postavljena je dijagnoza F 94.0 - selektivni mutizam. S obzirom na sveukupne teškoće, preporučena je stimulacija cjelokupnog razvoja, uključivanje u logopedski tretman, psihoterapijski tretman te, s obzirom na slabije savladane predškolske vještine i prisutne emocionalne teškoće, odgoda početka školovanja.

Dječak nakon timske obrade ostaje u kontinuiranom tretmanu logopeda te u kognitivno-bihevioralnom tretmanu psihologa. Psihološki tretman odvijao se kroz godinu i pol dana u ukupnom trajanju od 28 susreta s dinamikom u početku jednom tjedno, kasnije jednom u dva tjedna. Dječak i aktualno dolazi na „booster" seanse u cilju prevencije povrata simptoma te jačanja kapaciteta dječaka i roditelja, u frekvenciji jednom u tri tjedna.

\section{RASPRAVA}

Prema anamnestičkim podacima dobivenim od roditelja, dječak je iskazivao teškoće iz anksioznog kruga od ranog djetinjstva, koje nisu prepoznate i tretirane pravovremeno, te je, iako je već nekoliko mjeseci od dolaska na prvi pregled iskazivao teškoće u vidu selektivnog mutizma, tretman započet s odgodom. Prema Dodig-Ćurković i sur. ${ }^{5}$ često je slučaj da poteškoće u vidu selektivnog mutizma započnu između 3 . i 5. godine života, dok se dijagnoza postavlja tek kasnije, između 5. i 8. godine, zbog kompleksnosti prepoznavanja ovog poremećaja. Tome pridonosi i još nepotpuno razjašnjena etiologija poremećaja, budući da se koncept mutizma različito poimao kroz povijest. Ranije je bilo zastupljeno shvaćanje kako djeca „odbijaju govoriti“, dok suvremena shvaća- 
nja zastupaju teze o anksioznoj prirodi ovih teškoća ${ }^{12}$. Shvaćanja da dijete „odbija govoriti“ mogu značajno utjecati na poimanje samog poremećaja od strane socijalne okoline, te samim time i odgoditi početak terapije.

Psihomotorni razvoj dječaka je, prema podacima navedenima u studiji slučaja, kasnio s obzirom na očekivano za dob, kao i razvoj komunikacije, što je česta pojava kod djece s ovom dijagnozom ${ }^{1}$.

Kao što je ranije spomenuto, pregledom psihologa učinjena je, osim procjene intelektualnog funkcioniranja, i emocionalna procjena dječaka te je opservacijom i objektivnim psihologijskim mjerama utvrđena naglašena socijalna anksioznost, što je u skladu s podacima o učestalom komorbiditetu selektivnog mutizma $s$ drugim anksioznim poremećajima, prvenstveno sa socijalnom fobijom ${ }^{1,13}$. S obzirom na to da je dječak bio odvojen od roditelja neposredno prije početka teškoća, navedeni događaj možemo povezati i s postojećim hipotezama o selektivnom mutizmu kao formi separacijske anksioznosti ${ }^{14}$.

Roditelji su na početku tretmana upoznati s temeljnim postavkama kognitivno-bihevioralne terapije te njezine primjenjivosti na teškoće dječaka. Različiti teorijski pristupi predlažu i različite vrste tretmana, međutim, u metaanalizi 23 studije o psihološkim intervencijama, vezanima uz tretman selektivnog mutizma, upravo se kognitivno-bihevioralna terapija istaknula kao terapija izbora, uz multidisciplinarni pristup ${ }^{11}$, na koji je naglasak stavljen i u ovom prikazu.

Roditelji su prošli psihoedukaciju o poteškoćama vezanim uz dječakovu dijagnozu te su upoznati s važnošću postupnog tijeka tretmana, postavljanja malih i dostižnih ciljeva te potkrepljivanja sitnih pomaka u dječakovom ponašanju, kao i stavljanja manjeg naglaska na verbalnu komunikaciju u početku tretmana (ne tjerati dijete da govori, ne obraćati se grubim tonom ako šuti u nelagodnoj situaciji, u početku stavljati naglasak na neverbalne aktivnosti). Također, roditelji su upoznati s potrebom da kao roditelji koterapeuti primjenjuju dobivene savjete i terapijske tehnike s dječakom kod kuće. Uključivanje roditelja u bihevioralni tretman djeteta može imati važnu ulogu u izlječenju djeteta ${ }^{15}$. Kako bi se olakšala generalizacija efekata tretmana, roditelje se edu- cira da oni kao koterapeuti pomažu djetetu izvan terapijskih susreta ${ }^{16}$.

Roditeljima je nadalje pojašnjeno kako u situacijama kada kod dječaka izostaje verbalni odgovor, a oni odgovaraju umjesto njega, negativno potkrepljuju dječakovo ponašanje, što prema bihevioralnim teorijama samo učvršćuje djetetovo ponašanje i održava teškoće, a dijete ima sekundarnu dobit jer izbjegava anksioznost ${ }^{11}$, odnosno zadržavajući govor pokušava kontrolirati rastuću anksioznost ${ }^{17}$.

Rad stavlja naglasak na multidisciplinarni pristup u dijagnosticiranju i tretmanu poremećaja, te važnosti interakcije terapeuta, roditelja, škole i ostalih relevantnih sudionika djetetove socijalne okoline. U proučavanju ovog poremećaja tipično je objavljivanje studija slučaja djece, a buduća istraživanja trebaju precizirati metodološku proceduru i produbiti znanja o ovom rijetkom poremećaju.

Budući da je jedan od važnih aspekata selektivnog mutizma i drugih anksioznih poremećaja nemogućnost djeteta da se nosi s emocijama u stresnim situacijama ${ }^{18}$, s dječakom je inicijalno započeta afektivna edukacija kroz bojanku „Moja knjižica osjećaja“, kroz biblioterapiju („Miffy slikovnica kada se bojim“), emocionalni "memory“ te ostale interaktivne didaktičke materijale.

Dječak i roditelji dječaka poučeni su relaksacijskim tehnikama (abdominalno disanje i progresivna mišićna relaksacija za djecu), što je $s$ dječakom uvježbavano na seansama, a roditeljima su dane upute o važnosti primjenjivanja ove tehnike kod kuće. Tehnike relaksacije su se, u kombinaciji sa sistemskom desenzitizacijom, pokazale efikasnima u tretmanu selektivnog mutizma ${ }^{19}$, jer mogu poslužiti kao koristan alat za suočavanje pri izlaganju anksiogenim situacijama. Kod dječaka se provodila sistemska desenzitizacija kroz unaprijed dogovorenu listu zastrašujućih (anksiogenih) situacija (zastrašujuće situacije su u dogovoru s dječakom i roditeljima rangirane od 1 do 10, gdje je 1 predstavljao najmanje zastrašujuću situaciju, npr. šaptom reći „da“ u prisutnosti isključivo terapeuta, dok je 10 značilo predstaviti se u grupi djece i kratko reći nešto o sebi). S rodi- 
teljima je dogovorena jednostavna tehnika žetoniranja te su odabrani potkrepljivači za održavanje poželjnih oblika ponašanja (pohvale, skupljanje smajlića te zamjena za nagrade - slatkiše, ugodne aktivnosti kao što je kupanje u bazenu). U uredu terapeuta također se provodilo potkrepljivanje (kutija s malim igračkama iz koje bi dječak sam odabrao nagradu, uz unaprijed dogovorene ciljeve). Potkrepljivanje se pokazalo kao efikasan način motiviranja djece sa selektivnim mutizmom za sudjelovanje u tretmanu ${ }^{20}$.

Još jedna bihevioralna tehnika koja se učestalo primjenjuje kod ovakvih poteškoća je oblikovanje („shaping“), a može se uspješno primjenjivati i u školskom okruženju ${ }^{21}$. U radu s dječakom korištena je i ova tehnika te su se zahtjevi prema dječaku postupno povećavali. U početku je koristio samo neverbalnu komunikaciju kroz crtež, pokazivanje odgovora napisanog na papiru, kimanje glavom te nečujno izgovaranje riječi. $S$ dječakom je u početku korišteno kimanje glavom kao znak potvrde ili odbijanja te pokazivanje prstom na riječi „da“ i „ne“ napisane na papiru pred njim. Dok je dječak crtao, terapeut je cijelo vrijeme verbalizirao dječakove radnje (na primjer: „Pa ti si nacrtao sunce i cvijeće. To je baš predivna slika. Čini se da je na toj slici predivan dan, što kažeš?“), zatim bi dječak pokazivao na papiru „da“ ili „ne“. Ovaj oblik komunikacije, gdje se terapeut i dijete uključuju u zajedničku aktivnost, tako da pažnja bude usmjerena na aktivnost umjesto na dijete, efikasan je način poticanja dijaloga kod selektivnog mutizma22. Budući da pažnja nije usmjerena na dijete, dolazi do smanjenja razine anksioznosti, što olakšava djetetu sudjelovanje u dijalogu.

Predverbalna komunikacija odvijala se kroz tiho šaputanje kratkih riječi, u početku samo riječi "da“ i „ne“, te biranjem jednog od više ponuđenih sadržaja pomoću riječi „stop“.

U posljednjoj fazi ostvarena je verbalna komunikacija, prvo kroz telefonske kontakte dječaka i terapeuta; uz dolaske na terapiju također su razgovarali telefonom, dva puta tjedno. Nakon toga je dječak glasno izgovarao riječi okrenutih leđa terapeutu, zatim okrenut terapeutu, prekrivajući lice papirom, potom uz prisutnost jednog roditelja, bez papira, gledajući u terapeuta, te na- posljetku glasno izgovarajući riječi nasamo s terapeutom.

Korištena je i tehnika „stimulus fading“ kao tehnika operantnog uvjetovanja slična sistemskoj desenzitizaciji, koja se koristi u tretmanu socijalne fobije te se također pokazala učinkovitom u tretmanu selektivnog mutizma ${ }^{23,24}$. U početku je terapeut dolazio u hodnik gdje je čuo da dječak razgovara s roditeljima, a kasnije su u prostoriju uvedene nove osobe (vježbenice psihologije), dok je terapeut komunicirao s dječakom. U prvom slučaju su roditelji napuštali ordinaciju, a kasnije je terapeut napuštao ordinaciju, ostavljajući dječaka nasamo s psihologinjama vježbenicama.

Za poticanje spontane verbalizacije korištena je verbalno didaktička igra „Family stories“, koja prikazuje tipične dnevne aktivnosti obitelji, a zadatak je poredati šest slika prema točnom rasporedu i ispričati priču. U ovoj igri bilo je moguće i promijeniti tijek događaja, ispričati priču iz svoje perspektive te iz različitih perspektiva sudionika događaja. Roditelji su upotpunili i promijenili način obiteljskih druženja te nabavili mnoge obiteljske igre i igre za poticanje verbalnog razvoja (engl. "Story telling cubes“, „Alias“).

Kod dječaka je potican pozitivni samogovor, najprije unutarnji govor, zatim verbalizacija („Mogu ja to“, „Super sam to napravio“). S dječakom je korišteno i modeliranje - budući da dječak jako voli životinje nosio je sa sobom figuricu tigra koju je nazvao Tom, te je terapeut verbalizirao kako se tigar ponaša u određenim situacijama (držanje tijela, hrabrost, izdržljivost, snaga).

Uz sistemsku desenzitizaciju može se primijeniti i trening socijalnih vještina, iako je učinkovitost same te tehnike nedovoljno istražena, budući da se koristi u kombinaciji s drugim tehnikama, pa je teško izdvojiti poseban doprinos svake pojedine tehnike ${ }^{25}$. S dječakom je provođen trening socijalnih vještina kroz sudjelovanje u manjoj grupi djece slične dobi s Bolničkog odjela PB za djecu i mladež, kroz vježbanje osnovnih vještina - upoznavanje, predstavljanje, gledanje u oči, davanje komplimenata, uključivanje u igre suradnje, prepoznavanje i imenovanje osjećaja drugih.

$S$ dječakom je stavljen naglasak na bihevioralne tehnike, dok je s roditeljima rađeno na njihovim negativnim automatskim mislima o dječaku te 
predviđanju neuspješnosti dječaka u budućim situacijama („On je malo čudan.“, „Oduvijek je takav.", „Nije htio na jedan rođendan, pa nismo htjeli siliti dalje."). Budući da kognicije roditelja mogu loše utjecati na motivaciju, procjenu promjene te izvođenje bihevioralnih zadataka dječaka, korištena je tehnika pojačanog kognitivnog poučavanja roditelja ${ }^{26}$.

Prvi značajni rezultati tretmana koji su poboljšali sveukupno funkcioniranje dječaka uočeni su devet mjeseci od početka tretmana, kada je dječak i s nepoznatim osobama počeo komunicirati glasno, u rijetkim slučajevima šapatom. Prije polaska u 1. razred bez teškoća je počeo razgovarati s odgajateljima i djecom u vrtiću, nešto tišim glasom; pristao je otići pet dana na izlet bez roditelja te je sve proteklo bez poteškoća, lijepo se prilagodio i družio s djecom. Logopedski tretman dječaka završen je nešto prije psihološkog, a završni izvještaj logopeda glasio je da dječak glasnije i opuštenije spontano verbalizira te je pripremljen vježbama čitanja i pisanja za polazak u školu.

Dječak najesen polazi u školu te je terapeut, u dogovoru s roditeljima dječaka, napisao dopis za stručnu službu u obliku izvještaja o tijeku terapije u kojem su dane upute o načinima ophođenja s dječakom za vrijeme trajanja nastave. U tretmanu selektivnog mutizma sve se više koristi eklektički pristup, a školsko osoblje može imati važnu ulogu u tom procesu ${ }^{27}$. Dječakov terapeut je u kontinuiranom kontaktu sa školskom stručnom službom.

Dječak će zbog praćenja stanja dolaziti na psihoterapiju jednom u tri tjedna, a aktualno roditelji navode da nema većih poteškoća u funkcioniranju u školi. Dječak odlazi na dječje rođendane bez većih teškoća, no i dalje je povučeniji u skupini djece i ima manji broj prijatelja. Dječak u školi i aktualno govori tiše od ostale djece, povremeno i šapuće, no većinom glasno verbalizira i s djecom i s učiteljima, te izostaju kriteriji za daljnju dijagnozu selektivnog mutizma.

\section{ZAKLJUČAK}

Prikazan terapijski rad s dječakom ukazuje na učinkovitost intervencija u okviru kognitivno-bihevioralne terapije u radu s djecom s teškoćama iz anksioznog kruga, u ovom slučaju kod dječaka s postavljenom dijagnozom selektivnog mutizma, što je u skladu s relevantnim znanstvenim istraživanjima. Stresni životni događaji u predisponiranih pojedinaca u okviru specifične obiteljske dinamike i nedostatnih strategija suočavanja roditelja s teškoćama djeteta dovode do razvoja poremećaja. Ovaj rad stavlja naglasak na multidisciplinarni pristup u dijagnosticiranju poremećaja, važnost što ranijeg prepoznavanja problema te pravodobno tretiranje postojećeg poremećaja, kao i prevencije razvoja komorbidnih poremećaja. Ovim prikazom ističe se i važnost multidisciplinarnog pristupa u terapiji te važnost interakcije terapeuta, roditelja, škole i ostalih relevantnih sudionika djetetove socijalne okoline.

\section{Zahvale}

Zahvaljujem mr. sc. Nadi Anić, prof. psihologije te prim. Ljubici Paradžik, dr. med., spec. psih. na strpljivosti i stručnim savjetima koji mi uvijek pomažu u mom terapijskom radu s klijentima. Također zahvaljujem našim malim pacijentima od kojih uvijek iznova učimo i o terapijskom radu, ali i o sebi.

Izjava o sukobu interesa: Autori izjavljuju da ne postoji sukob interesa.

\section{LITERATURA}

1. American Psychiatric Association. Diagnostic and Statistical Manual of Mental Disorders. 5th ed. Washington D.C., 2013; 195-7.

2. Yeganeh R, Beidel DC, Turner SM. Selective mutism: more than social anxiety? Depression and Anxiety 2006;23:117-23.

3. Melfsen S, Walitza S, Warnke A. The extent of social anxiety in combination with mental disorders. European Child and Adolescent Psychiatry 2006;15:111-7.

4. Anstendig KD. Is selective mutism an anxiety disorder? Rethinking its DSM-IV classification. Journal of Anxiety Disorders 1999;13:417-34.

5. Dodig-Ćurković K, Benić D, Boričević Maršanić V, Ćurković $M$, Delalle $M$, Franić $T$ et al. Psihopatologija dječje i adolescentske dobi. Osijek: Svjetla grada, 2013; 109-15.

6. Kristensen H. Selective mutism and comorbidity with developmental disorder/delay, anxiety disorder and elimination disorder. J Am Acad Child Adolesc Psychiatry 2000;39:249-56.

7. Viana AG, Beidel DC, Rabian B. Selective mutism: A review and integration of the last 15 years. Clin Psychol Rev 2009;29:57-67.

8. Diliberto RA. Temperament and Behavior Factors in a Community Sample of Youth with Selective Mutism. Las Vegas: University of Nevada, 2017, PhD thesis. 
9. Egberts K, Seifert J. Elective (Selective) Mutism. In: Gerlach $M$, Warnke A, Greenhill L (eds). Psychiatric Drugs in Children and Adolescents. Vienna: Springer, 2014;362.

10. Kušević Z. Primjena antidepresiva u dječjoj i adolescentnoj dobi. In: Mihaljević Peleš A, Šagud M (eds). Antidepresivi u kliničkoj praksi. Zagreb: Medicinska naklada, 2009.

11. Cohan SL, Chavira DA, Stein MB. Practitioner review: Psychosocial interventions for children with selective mutism: A critical evaluation of the literature from 19902005. J Child Psychol Psychiatry 2006;47:1085-97.

12. Krysanski VL. A Brief Review of Selective Mutism Literature. J Psychol 2003;137:29-40.

13. Yeganeh R, Beidel DC, Turner SM. Selective mutism: More than social anxiety? Depress Anxiety 2006;23:117-23.

14. Dimoski S. Savremena shvatanja selektivnog mutizma. J Spec Educ Rehab 2016;15:347-69.

15. Wong P. Selective mutism: a review of etiology, comorbidities, and treatment. Psychiatry (Edgmont) 2010;7:2331.

16. Sulkowski ML, Pence SL, Carlson JS, Storch EA. Treating Selective Mutism with Exposure Therapy. Ann Psychother Integr Health 2014;1-23.

17. Anstendig KD. Is selective mutism an anxiety disorder? Rethinking its DSM-IV classification. J Anxiety Disord 1999;13:417-34.

18. Capozzi F, Manti F, Di Trani M, Romani M, Vigliante M, Sogos C. Children's and parent's psychological profiles in selective mutism and generalized anxiety disorder: a clinical study. Eur Child Adolesc Psychiatry 2018;27:775-83.
19. Suveg C, Comer JS, Furr JM, Kendall PG. Adapting Manualized CBT for a cognitively delayed child with multiple anxiety disorders. Clin Case Stud 2006;5:488-510.

20. Amari A, Slifer KJ, Gerson AC, Schenck E, Kane A. Treating selective mutism in a paediatric rehabilitation patient by altering environmental reinforcement contingencies. J Pediatr Rehabil 1999;3:59-64.

21. Austad LS, Sinninger R, Stricken A. Successful treatment of a case of elective mutism. Behav Ther 1980;3:18-9.

22. Oerbeck B, Stein MB, Wentzel-Larsen T, Langsrud $\varnothing$, Kristensen $\mathrm{H}$. A randomized controlled trial of a home and school-based intervention for selective mutism - defocused communication and behavioural techniques. Child Adolesc Ment Health 2014;19:192-8.

23. Dow SP, Sonies BC, Scheib D, Moss SE, Leonard HL. Practical guidelines for the assessment and treatment of selective mutism. J Am Acad Child Adolesc Psychiatry 1995;3:836-46.

24. Wulbert M, Nyman BA, Snow D, Owen Y. The efficacy of stimulus fading and contingency management in the treatment of elective mutism: A case study. J Appl Behav Anal 1973;6:435-41.

25. Busse RT, Downey J. Selective mutism: A Three-Tiered Approach to Prevention and Intervention. Contemp Sch Psychol 2011;15:53-63.

26. Stallard P. Misli dobro, osjećaj se dobro - kognitivno-bihevioralna terapija u radu s djecom i mladima. Jastrebarsko: Naklada Slap, 2010;75-98.

27. Kumpulainen K. Phenomenology and treatment of selective mutism. CNS Drugs 2002;16:175-80. 